\title{
Member state's lawlessness and European law - the case of Poland
}

\author{
ROBERT MEZYK \\ Australian Catholic University \\ Robert.Mezyk@acu.edu.au
}

\begin{abstract}
Since 2015 the Polish authorities have undertaken numerous actions subordinating the country's judiciary to political influence. These steps met resistance from the European Union (EU), including proceedings by the European Commission and at the Court of Justice of the European Union (ECJ). The judgement of the ECJ in the case A.K. and Others $v$ Sad Najwyższy (2019) brought the situation to another level by empowering national courts to verify the independence of other domestic judicial bodies. While the ECJ empowered Polish judges to reject the domestic court-packing, the Polish state countered this with internal disciplinary sanctions. I discuss this tension and consider the upcoming conflict between the ECJ and the Polish Constitutional Tribunal ('CT'). I conclude by highlighting the fact that whereas Poland breaches European law, the breach will be hard to rectify due to the lack of independent enforcement mechanisms on the side of the EU.
\end{abstract}

Keywords: European Law, Rule of law, Poland, European Court of Justice, the Polish Constitutional Tribunal, the infringement procedure

\section{Introduction}

Since a landslide electoral victory in 2015 by the Law and Justice Pary (PiS) ${ }^{1}$, Polish authorities have been increasing their political influence on the functioning of the judiciary. These actions challenge the principles of judicial independence anchored in Art. 19 of the Treaty on the European Union (TEU)2 ${ }^{2}$, Art. 47 of the Charter of Fundamental Rights ('Charter') 3 and Art. 2 TEU4. So far, the EU has remained largely ineffective in counteracting this 'reform': The dialogue between the European Commission and the Polish government within the non-binding mechanism of the

\footnotetext{
${ }^{1}$ In the 2015 elections Law and Justice (pol. Prawo i Sprawiedliwość) won 235 out of 460 seats in the Polish Parliament (("PKW | Wybory Do Sejmu RP i Senatu RP 2015” 2015)). PiS repeated its success in 2019, winning the same number of seats ("Wyniki wyborów 2019 do Sejmu RP" 2019)).

${ }^{2}$ Art. 19 par. 2 TEU: '(...)Member States shall provide remedies sufficient to ensure effective legal protection in the fields covered by Union law.'

3 Art. 47 of the Charter: '(...) Everyone whose rights and freedoms guaranteed by the law of the Union are violated has the right to an effective remedy before a tribunal in compliance with the conditions laid down in this Article. (...)'

4 'Art. 2 TEU: 'The Union is founded on the values of res pect for human dignity, freedom, democracy, equality, the rule of law and respect for human rights, including the rights of persons belonging to minorities. These values are common to the Member States in a society in which pluralism, non-discrimination, tolerance, justice, solidarity and equality between women and men prevail.'
} 
Rule of Law Framework 5 remained futile. At the same time, the requirement of unanimity of other member states has exposed the inherent weakness of the "nuclear" rule of law mechanism from Art. 7 TEU. ${ }^{6}$ On this background, the judicial procedures at the ECJ could be the only viable mechanism of hindering the Polish rule of law backsliding.

This article discusses the clash between the European rule of law and the principle of primacy of European law on one side, and national law and politics on the other. After describing the background of the Polish rule of law debacle, I discuss the ECJ's ruling A.K. and Others $v$ Sąd Najwyższy ('A.K.' judgement) (Case C-585/18,A.K. and Others v Sąd Najwyższy 2019) and its consequences for safeguarding the independence of the Polish judiciary. One of the most critical outcomes in this respect is a conflict between the principle of primacy of European law and the reality created by the Polish government which deters the domestic courts from following the ruling of the ECJ.

After describing the measures already undertaken by the Polish government against the A.K. judgement, I discuss the intended use of the Polish Constitutional Tribunal ('CT') as a tool in shielding the Polish 'reform' of the judiciary from the interference from ECJ. Whereas from the side of the Polish state, the CT constitutes the highest instance of the judiciary, from the European law perspective the CT, and other statecaptured courts, are merely tools used by the state to further its policies. Thus, the article concludes by discussing the dynamics of the conflict between European jurisdiction and the Polish authorities.

\section{Background: the assault on Polish courts}

The measures applied by the Polish authorities to the national system of the judiciary are characteristic for illiberal democracies or authoritarian regimes (Sadurski 2019, 242-61). Such systems aim at concentrating power in the hands of a political leader or organisation, and the independence of judges threatens this agenda. An authoritarian rule benefits from packing top judicial institutions and concentrating the politically significant decisions in their hands; establishing new super-courts controlled by the authorities; and from extending a net of formal and informal mechanisms of dependency which aim at controlling the ordinary courts (Sanchez Urribarri 2011; Solomon 2007). Through these measures, the regime avoids challenges by judicial independence. Additionally, the capture of courts allows to use the judiciary as a seemingly impartial facilitator of political changes and to strengthen the legitimacy of the authoritarian regime through compliant case-law (Solomon 2007, 128).

The Polish authorities have been challenging the independence of the judiciary both at the level of ordinary courts and the country's highest judicial institutions (Sadurski 2019, 58-95). These actions included illegal "cancelling" of the previous election of some of the judges of the Constitutional Tribunal and a set of legislative measures aimed at paralysing this institution. PiS blocked the functioning of the CT until the cadencies of the non-compliant judges have finished, and the Parliament replaced

\footnotetext{
5 The Rule of Law Framework is a procedure introduced by the European Commisison in 2014. This procedure structures the dialogue between the Commission and the member states. However, it does not offer any binding mechanisms or sanctions. See: ("Rule of Law Framework" n.d.).

${ }^{6}$ Art. 7 TEU allows the European Council to 'to suspend certain of the rights deriving from the application of the Treaties' in relation to a meber states which breaches the principles of the EU from art. 2 TEU. However, the procedure requires unanimity of other member states.
} 
them with candidates supported by PiS (Sadurski 2019, 116). Furthermore, the Polish authorities launched a comprehensive set of measures aimed at packing the country's Supreme Court and lower courts. These measures included extending the powers of the Presidents of the ordinary courts and replacing the pre-PiS court presidents with nominees of the Minister of Justice (Sadurski 2019, 112).

Furthering the control over the national judiciary, the Polish Parliament enacted laws which created a system of disciplinary responsibility of the judges, headed by a newly created Disciplinary Chamber of the Polish Supreme Court ('Disciplinary Chamber') (Sadurski 2019,110-15). The members of this Chamber were elected by the "reformed" National Council of the Judiciary ('NCJ'). The NCJ performs crucial functions regarding the supervision of the judiciary, including the competence to propose candidates for appointment as a judge and safeguarding the independence of courts and judges (The Constitution of the Republic of Poland 1997, Art. 179 and 186). Breaching the country's Constitution, PiS has removed the pre-2015 members of the NCJ and appointed its candidates (Sadurski 2019, 98-106). The NCJ then staffed the Disciplinary Chamber with people directly linked to PiS or its Minister of Justice ("To Oni Zajmą Się Przewinieniami Kolegów Po Fachu.” 2018). These actions cumulatively led to a situation in which PiS controls the Constitutional Tribunal and the NCJ, and systematically strengthens its grip on the rest of the judiciary.

In response to the described measures by the Polish authorities, the European Commission initiated treaty infringement procedures at the ECJ. The impugned Polish rules were forcing judges of chosen courts to retire earlier than initially foreseen and differentiated their retirement age according to sex. A possible continuation of the judges' service depended then on a discretionary decision of the Republic's President (a PiS-politician) (Case C-619/18 European Commission v Republic of Poland 2019). Apart from challenging the discriminatory aspect of these solutions, the ECJ asserted the competence to control the independence and impartiality of national courts by extensively interpreting the second subparagraph of Art. 19 (1) TEU. The norm states that the 'Member States shall provide remedies sufficient to ensure effective legal protection in the fields covered by Union law'. The ECJ reaffirmed its views from the ASJP judgement (Case C-64/16, Associação Sindical dos Juízes Portugueses v Tribunal de Contas 2018) and stated that because the national courts apply European law, Art. 19 (1) TEU warrants their independence and impartiality (Case C-192/18, European Commission v Republic of Poland 2019, para. 47). However, because of the scope and nature of the mentioned infringement procedures, the ECJ's judgements had left open such systematic issues as the NCJ capture, the political nominations of judges designated to work at the Disciplinary Chamber and the strengthened system of disciplinary responsibility of judges. The opportunity to rule on these matters presented itself with the request for a preliminary reference in the case $A . K$.

\section{The $A . K$. judgement}

The case $A . K$. resulted from a dispute concerning the early retirement of Polish judges sitting in the country's Supreme Administrative Court and the Supreme Court. New Polish legislation lowered the retirement age for the judges of these two courts from 70 to 65 years. Should the judges wish to continue working after they reached the age of 65, they required a discretionary approval of the President of the Republic, based, 
among others, on a positive opinion by the NCJ. 7 Three judges have challenged the decisions or declarations issued in their cases and lodged actions at the Labour and Social Insurance Chamber of the Polish Supreme Court ('LSI Chamber'). According to the new legislation, affected judges should direct such claims to the Disciplinary Chamber. However, at the moment of lodging the claim, the authorities had not yet established the Disciplinary Chamber, and the case went first to the LSI Chamber comprising of 'regular' judges (not PiS-nominees). After the Disciplinary Chamber started functioning, the LSI Chamber was obliged to transfer the case to it. Nevertheless, considering the doubts surrounding the Disciplinary Chamber, the LSI Chamber decided to apply to ECJ for a preliminary ruling regarding the transfer of the case. The core of the question consisted of enquiring whether the LSI Chamber should interpret the European law in a way which would prevent the claims of the three judges from being transferred to, and decided by, the Disciplinary Chamber.

The relevant European law in the case was Art. 19 TEU, Art. 47 of the Charter and Article 9(1) of Council Directive 2000/78/EC of 27 November 2000 establishing a general framework for equal treatment in employment. The latter act was applicable in the case because the applicants based their claims, among others, on the prohibition of discrimination in employment on the ground of age. The Directive 2000/78/EC requires that the member states establish effective judicial remedies for challenging discriminatory treatment(Case C-585/18, A.K. and Others v Sąd Najwyższy 2019, para. 80 ). This requirement then opens the gate to the assessment of the domestic judicial institutions in the light of European law, including the Charter. ${ }^{8}$

In its judgement, the ECJ spelled out the requirements which apply to a judicial body deciding the matters of European law. The ECJ based these requirements on Art. 47 of the Charter which states that "Everyone is entitled to a fair and public hearing within a reasonable time by an independent and impartial tribunal previously established by law". From this provision, ECJ derived the conclusion that the applicants in the domestic judicial system are entitled to a fair hearing by an independent and impartial tribunal (Case C-585/18, A.K. and Others v Sąd Najwyższy 2019, para. 120). According to the ECJ, "independence" means that the judges are protected from external intervention or pressure and should be free from direct or indirect influence affecting their decisions (Case C-585/18,A.K. and Others v Sąd Najwyższy 2019, para. 125). The requirement of Impartiality implies that the judges' behaviour and connections cannot raise doubts regarding their neutrality. At the same time, their objective qualities and events surrounding the court proceeding should also confirm its impartiality (Case C$585 / 18, A . K$. and Others v Sąd Najwyższy 2019, para. 128).

The A.K. judgement underlines the importance of the principle of primacy of European law. This principle means that the EU law, including the European case-law, enjoy supremacy over domestic laws. Such an effect has significant consequences in the application of the $A . K$. judgement by the courts of the member states: Should a domestic court decide that a provision of national law deprives someone of adequate judicial protection, the court should leave such provision unapplied. Thus, when

\footnotetext{
7 The statute lowering the retirement age of judges was revoked in reaction to a treaty infringement procedure at the ECJ in case C-619/18 (Case C-619/18 European Commission v Republic of Poland 2019). However, this did not remove all the consequences of the earlier law which allowed the ECJ to proceed in the case $A . K$.

${ }^{8}$ According to Art. 51 of the Charter, the Charter applies to the Member States 'only when they are implementing Union law'. This is why it is important that the case of the judges fell within the scope of European law through the Directive 2000/78/EC.
} 
national law obliges a court to transfer a case to another judicial body, the court may refuse to do so if the other body is not impartial (Case C-585/18,A.K. and Others v Sąd Najwyższy 2019, para. 156).

In the A.K. judgement, the ECJ refrained from declaring whether the NCJ or the Disciplinary Chamber fulfil the requirements of independence or impartiality. Instead, the ECJ empowered the referring court to decide these questions. Nevertheless, the judgement contains several remarks indicating that the doubts regarding the impartiality of the Disciplinary Chamber are justified. These indices include the fact that the authorities extraordinarily shortened the term in office of the previous NCJ's and that political authorities now elect 23 of its 25 members (Case C-585/18,A.K. and Others v Sąd Najwyższy 2019, para. 143). Furthermore, the ECJ stressed that the domestic court should consider all aspects of the functioning of the Disciplinary Chamber. These include the lowering the retirement age of the judges of the Supreme Court (which the Disciplinary Chamber is a part of), and forming the Disciplinary Chamber solely from newly appointed judges (Case C-585/18, A.K. and Others v Sąd Najwyższy 2019, pts. 147-150). The judgement further states that although one or other of the factors taken individually may escape criticism, the domestic court needs to see them in context and evaluate them as a whole (Case C-585/18, A.K. and Others v Sąd Najwyższy 2019, para. 142). Should the verification give negative results, then

"Article 47 of the Charter and Article 9(1) of Directive 2000/78 must be interpreted as precluding cases concerning the application of EU law from falling within the exclusive jurisdiction of a court which is not an independent and impartial tribunal, within the meaning of the former provision"(Case C585/18, A.K. and Others v Sąd Najwyższy 2019, para. 154).

In other words, the domestic court should ignore the domestic provision, which asks it to transfer a case to a judicial body which is not impartial or independent.

\section{Polish courts and the principle of primacy}

The A.K. judgement presumes that the EU and the Polish legal systems constitute a unity characterised by the primacy of European law. This assumption follows from the fact that Poland ratified the European Treaties and accepted the European acquis. As the court re-stated in the ruling, the EU law stems from a source of law independent from the member states and thus enjoys primacy and direct effect in the member states (Case C-585/18, A.K. and Others v Sąd Najwyższy 2019, para. 156). However, the Polish case counters this assumption and exposes the gap in rule enforcement by the EU: Because the EU does not have a law enforcement apparatus itself, it relies on the cooperation from the side of the domestic systems. This reliance is problematic in the case of Poland.

The EU sanctions the breaches of European law by its member states via the infringement procedure from Art. 258 TFEU. This procedure leads to only a general responsibility of these states. In effect, breaches of the law are "penalised" with delay needed to run the European procedure, and no individual (personal) responsibility takes place. Meanwhile, the individuals who, in the conflict between the EU and a member state, follow European law and challenge the national system, face direct negative consequences from the side of the domestic apparatus. Thus, the European 
law, with its remote and general sanctions, competes with national norms sanctioned by direct and individual consequences attached to their breach.

In the previous applications of the principle of primacy, the ECJ obliged the national judges to disregard domestic laws of governments which recognised their obligations from European law. In the Polish case, judges face systemic hostility of the state's administration towards the EU. Consequently, a domestic judge who applies European law contrary to the expectations of national authorities no longer executes the law (in the eyes of the member state) but breaches it. Accordingly, the judges make themselves vulnerable to sanctions imposed by the member state. Considering this reality, the theoretical construct of the $A . K$. judgement empowers the national courts to undertake a seemingly suicidal mission. Even though a judge who applies the $A . K$. judgement will behave correctly, she will face a national system aimed against her. The correctness in applying European law is thus balanced by human needs and fears of judges, such as the need to earn their living, the maintaining their judicial career or the wish to avoid disciplinary proceedings or criminal charges from the side of a corrupt system.

Therefore, it is doubtful that Polish judges, or other judges in authoritarian regimes within the EU, would widely apply the $A . K$. ruling. Such an application would require an introduction of an effective sanctioning mechanism on the European level to protect the national judges. This unfulfilled need indicates that the $A . K$. judgement is just a step in counteracting the Polish court-packing and not a tool to be applied by the domestic courts. Still, the case potentially delegitimises and dismantles the Polish system of the judiciary established by PiS, as explained in the next section.

\section{$5 \quad$ European law and purely domestic context}

Although the A.K. judgement concentrates on the interpretation of Art. 47 of the Charter, the reasoning regarding the requirement of independence and impartiality of courts also applies to Art 19 (1) TEU. According to the ECJ, Art. 19 (1) TEU "is a general principle of EU law which is now enshrined in Article 47 of the Charter" (Case C585/18, A.K. and Others v Sąd Najwyższy 2019, para. 168). After the A.K. judgement it is clear that the former norm cannot be infringed without infringing the latter. The requirements of impartiality and independence always apply, irrespective whether a case considers European law. If a member state maintains courts which are not independent or impartial, it breaches Art. 19 TEU irrespective of the context of an individual case because all domestic courts may decide issues of European law (Case C-619/18 European Commission v Republic of Poland 2019, para. 56).9 This conclusion leads to significant consequences not only for assessing the breach of law on the side of the member state but also for the conduct of judges in purely domestic cases.

Because all domestic authorities are obliged to sincerely cooperate with the EU and support the achievement of its goals, the domestic courts also should refrain from supporting mechanisms and institutions aimed at breaching European law. In the Polish context, it is notorious that the Polish NCJ is a governmental body not fulfilling its judicial function; that the Polish Constitutional Tribunal is a political extension of the authorities and not a court; and that the Disciplinary Chamber is a jurisdictional hoax. Thus, other courts, both Polish and from other member states, should refrain

9 Case C-619/18, European Commission v Republic of Poland, EU:C:2019:531, para 56. 
from cooperating with these bodies and effectively ignore their judgements or decisions. Consequently, the case-law of the ECJ leads to the dismantling of the Polish system of the judiciary established by PiS. However, before this theoretical construct has practical consequences, the not insignificant obstacle in the form of the resistance from the Polish authorities needs to be overcome.

\section{Counteracting the $A . K$. judgement}

The competence granted by the $A . K$. judgement to the referring court has been executed by the referring LSI Chamber of the Supreme Court to the detriment of the Disciplinary Chamber of the same court. The LSI Chamber decided the NCJ is neither independent nor impartial. Instead, the NCJ is directly dependent on the executive and legislative. For this reason, the Disciplinary Chamber, which the NCJ constituted, shares the NCJ's faults and is not a court according to European, and hence, the Polish law. Consequently, the LSI Chamber refused to transfer the case to the Disciplinary Chamber and disapplied the national rules of jurisdiction (Case III PO 7/18 2019).

A few days after the A.K. ruling, a judge of a District Court attempted to follow the ECJ judgement and verify the impartiality and independence of the National Council of the Judiciary. Shortly afterwards, the judge's supervisor (President of his court) suspended him from his duties ("Sędzia Paweł Juszczyszyn zawieszony." 2019). The disciplinary prosecutor raised charges against the judge, including an allegation of committing a crime of overstepping his competencies ("Komunikat Rzecznika Dyscyplinarnego sędziego Piotra Schaba” 2019).

The Polish authorities demonstrated a clear intention to thwart any further applications of the A.K. ruling in Poland. The Minister of Justice announced that the ECJ could not decide about the Polish "reform" of courts ("Wyrok TSUE Ws. Sądu Najwyższego. Zbigniew Ziobro: Trybunał Orzekł to, Czego Się Spodziewałem” 2019). At the same time, PiS modified the statutory regime of disciplinary control over Polish Judges ("Disciplining Law") (Ustawa z dnia 20 grudnia 2019 r. o zmianie ustawy Prawo o ustroju sądów powszechnych, ustawy o Sądzie Najwyższym oraz niektórych innych ustaw 2019). The new law directly contradicts the A.K. judgement by prohibiting the courts from questioning the legality of other courts and tribunals, as well as of other constitutional, controlling or law enforcement bodies (Ustawa $z$ dnia 20 grudnia 2019 r. o zmianie ustawy - Prawo o ustroju sądów powszechnych, ustawy o Sądzie Najwyższym oraz niektórych innych ustaw 2019 Art. 1 point 19 ). Additionally, according to the law, the judges can be punished for actions or lack of actions which would seriously impair the functioning of the judiciary; actions which would question the legality of the nomination of a judge; for public activity which cannot be reconciled with the principles of independence of the judges and courts; and for infringing the dignity of the judge's position (Ustawa $\mathrm{z}$ dnia 20 grudnia $2019 \mathrm{r}$. $\mathrm{o}$ zmianie ustawy - Prawo o ustroju sądów powszechnych, ustawy o Sądzie Najwyższym oraz niektórych innych ustaw 2019 Art. 1 points 32-33). The catalogue of penalties for these delicts includes removing the judge from her office (Prawo $o$ Ustroju Sądów Powszechnych 2001 Art. 109).

The current procedural design of the disciplinary system furth er strengthens the grip of PiS on the judiciary. The disciplinary procedure in the first instance takes place in the disciplinary courts at the courts of appeals and, in the second and final instance, in the Disciplinary Chamber (Prawo o Ustroju Sąów Powszechnych 2001 Art. 110). 
The President of the Disciplinary Chamber indicates the court of the first instance in a given case (Prawo o Ustroju Sąów Powszechnych 2001 Art. 110 § 3). Moreover, the prosecutor in such cases is a functionary designated by the Minister of Justice (Prawo o Ustroju Sądów Powszechnych 2001 Art. 112 § 3).

The Polish Ministry of Justice endorsed the Disciplining Law ("Stanowisko Ministerstwa Sprawiedliwości w sprawie zmian dotyczących aktywności sędziów" 2019). The Ministry stated that the project was necessary to rectify the chaos created by the $A . K$. ruling and served the purpose of the ruling's implementation. The statement also underlined the exclusive competence of the CT to control the legality of laws within Poland. In this context, the Polish Minister of Justice stated that according to the Polish Constitution, the final decision regarding the organisation of the Polish judiciary belongs to the Polish Constitutional Tribunal. The respective procedure is already pending at the CT (Procedure K/718).

\section{Breach of European law}

The activities of the Polish state concerning the A.K. ruling are a violation of European law. Firstly, the breach consisted of forming a judiciary system in which European law is being actually or potentially applied by courts lacking independence and thus violating Art. 47 of the Charter and Art. 19 (1) TEU. Secondly, Poland actively pursues the goal of depriving a judgement of the ECJ of its force. This activity contradicts the country's duty of sincere cooperation enshrined in Art. 4 (3) TEU, according to which member states shall assist the EU in carrying out its tasks.

Polish courts, which are theoretically co-responsible for the enforcement of European law, can hardly rectify the described breaches because of the described court-packing scheme. However, the conflict between the two legal systems does not end in the described stalemate. In April 2020 the ECJ has issued an interim order in the infringement procedure which the European Commission has initiated against Poland (Order in the case Case C-791 Commission v Poland 2020). In the order, the ECJ suspended the operation of the Disciplinary Chamber until the ECJ issues a ju dgement in the main procedure (Order in the case C-719/19 Commission v Poland 2020).

In reaction to the interim order, the Polish government again challenged the competence of the ECJ in the case. The government's spokesman announced that the Polish Prime Minister would apply to the Constitutional Tribunal for a decis ion on the matter ("Reakcja premiera na decyzję TSUE" 2020).

\section{The Polish Constitutional Tribunal}

The Polish Constitutional Tribunal sits at the top of the Polish judiciary and issues judgements which are universally binding and final (The Constitution of the Republic of Poland 1997 Art. 190 (1)). The CT had issued a judgement which follows the line adopted by the German Federal Constitutional Court in its Maastricht case and set a domestic limit to the principle of primacy of European law (Madsen and Hofmann 2018). In the judgement from 2010, the CT stated that the Polish Constitution remains the highest law of Poland (Case K 32/o9 Traktat z Lizbony 2010). Consequently, the Polish CT, similar to its German counterpart, can exceptionally verify whether an act of the European institutions contravenes the specific empowerment assigned to them 
by the European Treaties. However, the Polish Constitutional Tribunal from 2010 was very different from the CT of 2019.

The court-packing applied by PiS to the CT delegitimises the latter as a judicial institution (Sadurski 2019, 58-95). Since 2015 PiS prevented legally elected members of the Tribunal from taking office: the Polish President did not accept their oath in a violation of the country's Constitution. PiS illegally "invalidated" the election of these judges by the previous Parliament and elected other candidates for the already occupied vacancies at the Tribunal. The Polish President hastily took the oaths of these candidates in the late-night hours to outrun a judgment by the CT on the legality of these re-elections (Sadurski 2019, 58-95). A legally doubtful capture of the office of the President of the Tribunal by a PiS-supported candidate followed. This President of the CT then illegally removed the CT's vice-president by sending him on holidays for several months (Sadurski 2019, 63-68). Consecutively, PiS used its majority in the Polish Parliament to elect "own people" to fill the vacancies which later appeared at the Tribunal. Adding insult to injury, in December 2019 the Polish Parliament elected two of the most active PiS hardliners to join the court as its judges. These candidates - Krystyna Pawłowicz and Stanisław Piotrowski - had initially been responsible for preparing the "reform" of the judiciary by PiS. Consequently, by January 2020, 14 out of 15 judges have been nominated by PiS.

The functioning of the CT after its capture is also legally doubtful. The PiS-nominated President of the CT is known to have been manipulating (as long as this was necessary) the compositions of the panels to dominate them by judges nominated by PiS (Sadurski 2019, 69). At the same time, the bias in the works of the Tribunal towards $\mathrm{PiS}$ is obvious. The CT, on numerous occasions, has demonstrated active support for PiS, facilitated its initiatives and accepted laws inconsistent with the institution's settled case-law (Sadurski 2019, 69). The publicly admitted friendship of the CT's President and Jarosław Kaczyński (the political leader of PiS) fulfils the image of the court as a political extension of PiS ("Jarosław Kaczyński: Julia Przyłębska to Moje Towarzyskie Odkrycie”2019).

In the context of the A.K. judgement, the described characteristics of the Tribunal raise legitimate doubts regarding the body's impartiality and independence. Consequently, in the language of the A.K. judgement, the Tribunal cannot be "seen to be independent or impartial with the consequence of prejudicing the trust which justice in a democratic society must inspire in subjects of the law" (Case C-585/18, A.K. and Others v Sąd Najwyższy 2019, para. 171). The lack of impartiality and independence of the Constitutional Tribunal preclude the CT from judging cases which involve, or may involve, European law. Still, the CT will most likely hand down a judgement declaring the ECJ's involvement with the Polish court "reform" ultra vires. This step leads then to an infringement procedure against Poland on the side of the EU.

\section{The logic of the conflict with member states' top courts}

Hitherto, the European Commission and the ECJ have shown rem arkable restraint in dealing with national highest courts and tolerated the rare cases of their rebellious attitude regarding the primacy of European law (O'Sullivan 2018). However, these situations involved genuine national judicial institutions in a relatively insignificant context. Examples include the Czech Constitutional Court refusing, in 2012, to accept ECJ's judgement regarding the calculation of pensions for workers from former 
Czechoslovakia (Madsen and Hofmann 2018, 265). In another case, the Danish Supreme Court resisted ECJ ruling in a proceeding regarding the application of the principle of EU law prohibiting discrimination on the grounds of age (Madsen, Olsen, and Sadl 2017). In the case Tarrico, the Italian Constitutional Court disagreed with the ECJ preliminary ruling regarding Italian limitation laws in the area of tax fraud prosecution (O'Sullivan 2018). The case of the Polish Constitutional Tribunal would be qualitatively different from the mentioned cases for several reasons.

Firstly, the judgement of the CT would protect a clear violation of the rule of law and the advancement of an authoritarian regime. This process does not compare to the relatively minor questions of pension payments (Czechia), age discrimination in a horizontal setting (Denmark) or limitation period (Italy). As much as the ECJ could tolerate the non-compliance in these cases, the Polish situation relates to the very foundations of the European legal system and directly affects the dispersed system of law enforcement through the member states' courts.

Secondly, the ECJ and the Commission have exercised caution regarding the infringements of European law performed by the judicial bodies because of the respect for the principle of judicial independence (Madsen and Hofmann 2018). The infringement procedures address the member state's governments and thus imply that they can rectify the breach of law which the procedure challenges, possibly limiting judicial independence. However, this reason for the restraint does not apply to the Polish CT: The CT is neither independent nor impartial in the first place.

The third reason for the exceptional nature of the situation is the dependence of the CT on the Polish government. The European Treaties based the EU's system of the Judiciary on judicial cooperation between the courts, in which the courts treat each other as partners in applying the law. Because of the composition and the operations of the CT, the latter no longer is such a partner. To the contrary, it constitutes a tool of governmental control within the judiciary, aimed at dismantling the influence of European law on the Polish system. Consequently, an open judicial conflict with this body is in the interest of securing the rule of law in the EU.

\section{The infringement procedure}

On the 10th of October 2019, the European Commission triggered an infringement procedure against Poland 'to protect judges in Poland from political control' ("Rule of Law: European Commission launches infringement procedure to protect judges in Poland from political control" 2019). In the procedure, the Commission stated that the current Polish law subjected court judges to disciplinary sanctions which impede the exercise of their rights under Art. 267 TFEU (a preliminary reference to the ECJ) ${ }^{10}$. Furthermore, the Commission highlighted the lack of independence and impartiality of the Disciplinary Chamber of the Supreme Court and its extensive powers leading to an impediment of the judges' independence.

The ongoing fight of the government (and potentially the Constitutional Tribunal) against the application of the judgement $A . K$. in Poland constitutes a separate ground for an infringement procedure closely related to the one initiated by the Commission. As mentioned above, this is because these actions are an infringement of the obligation

${ }^{10}$ In this procedures domestic courts of member states may request the ECJ to give an opinion (preliminary ruling) on the interpretation of European law. 
of sincere cooperation from Art. 4 (3) TEU, and respective rules relating directly to the functioning of the judiciary.

After ECJ hands down a judgement in the infringement procedure, the member states should implement it and rectify the breach. If the member state fails to do so, the Commission may initiate the sanctioning mechanism from Art. 260 (2) TFEU. In this procedure, the European Commission may bring a case before the ECJ if it considers that the Member State concerned has not taken the necessary measures to comply with the judgment of the court. The European Commission shall specify the amount of the lump sum or penalty payment to be paid by the Member State concerned which it considers appropriate in the circumstances. Should the Court declare that the member state indeed has not complied with the judgement, it may impose the lump sum or penalty both separately and cumulatively.

The European Commission can execute the fines from the financial benefits Poland is receiving from the EU. As these payments are still significant, the sanctions could have a chilling effect on the Polish economy. Furthermore, the imposition of a penalty payment justified by the capture of the judiciary would have profound political meaning: It would demonstrate to the Polish population that the policies of its government are causing direct damage to the nation's wellbeing. However, it remains to be seen whether the sanctions rectify the situation in Poland or merely strengthen the tension surrounding the authoritarian transformation of the country.

\section{Conclusion}

The Polish rule of law debacle challenges the European system and tests its political resistance to the lawlessness of an authoritarian state. The $A . K$. ruling provides for a significant escalation of this conflict. The ECJ indirectly challenged the lawfulness of the Polish court-packing which leads to a delegitimisation of the politicised judicial bodies. Furthermore, the A.K. judgement creates a systemic threat to the political control over the Polish judiciary even in the purely domestic context, as all European courts potentially apply European law and should be independent and impartial. Thus, Polish and European judges are empowered and obliged to refrain from cooperating with such institutions as the Polish NCJ, the Disciplinary Chamber of the Supreme Court or the Polish Constitutional Tribunal.

The development of the described conflict depends on the attitude and courage of the Polish judges. The ECJ has empowered them to reject cooperation with already captured judicial bodies. Yet, such disobedience may expose the judges to significant personal risks applied through the system of disciplinary responsibility. Consequently, the situation reveals a weakness of the European project consisting of a lack of enforcement mechanisms, independent of the member states.

Considering the unambiguously adverse and assertive reaction of the Polish authorities to the A.K. judgement and its implementation, the breach of European law perpetuated by Poland is likely to continue. The Polish authorities have indicated their next steps in this conflict which consist in strengthening the system of oppressing noncompliant judges and using the Constitutional Tribunal to enhance the standing of Poland vis a vis the ECJ. However, this will expose the fact that the CT itself is not a court in the light of European law. 


\section{Bibliography}

Case C-64/16, Associação Sindical dos Juízes Portugueses v Tribunal de Contas. 2018. Court of Justice of the European Union.

Case C-192/18, European Commission v Republic of Poland. 2019. Court of Justice of the European Union.

Case C-585/18,A.K. and Others v Sąd Najwyższy. 2019. Court of Justice of the European Union.

Case C-619/18 European Commission v Republic of Poland. 2019. Court of Justice of the European Union.

Case III PO 7/18. 2019. Supreme Court of Poland.

Case K 32/o9 Traktat z Lizbony. 2010. Polish Constitutional Tribunal.

“Jarosław Kaczyński: Julia Przyłębska to Moje Towarzyskie Odkrycie.” 2019. May 13, 2019. https://www.wprost.pl/polityka/10216240/jaroslaw-kaczynski-juliaprzylebska-to-moje-towarzyskie-odkrycie.html.

"Komunikat Rzecznika Dyscyplinarnego sędziego Piotra Schaba.” 2019. Rzecznik Dyscyplinarny Sędziów Sądów Powszechnych. November 29, 2019.

http://rzecznik.gov.pl/2019/11/komunikat-rzecznika-dyscyplinarnego-w-sprawiewszczecia-postepowania-dyscyplinarnego-przeciwko-pawlowi-j-sedziemu-sadurejonowego-w-olsztynie/.

Madsen, Mikael Rask, and Andreas Hofmann. 2018. "Resistance against the Court of Justice of the European Union" 14 (2): 258-274.

https://doi.org/10.1017/S174455231800006X.

Madsen, Mikael Rask, Henrik Palmer Olsen, and Urška Šadl. 2017. “Competing Supremacies and Clashing Institutional Rationalities: The Danish Supreme Court's Decision in the Ajos Case and the National Limits of Judicial Cooperation."

European Law Journal 23 (1-2): 140-150. https://doi.org/10.1111/eulj.12215.

Order in the case C-719/19 Commission v Poland. 2020. Court of Justice of the European Union.

Order in the case Case C-791 Commission v Poland. 2020. Court of Justice of the European Union.

O’Sullivan, Rachel. 2018. "Burning Bridges? The Court of Justice and the Autonomy of the EU Legal Order." Hibernian Law Journal 17: 1-24.

“PKW | Wybory Do Sejmu RP i Senatu RP 2015.” 2015. 2015. https://parlament2015.pkw.gov.pl/349_Wyniki_Sejm.html.

Prawo o Ustroju Sądów Powszechnych. 2001.

"Reakcja premiera na decyzję TSUE.” 2020. April 8, 2020.

https://fakty.interia.pl/raporty/raport-unia-europejska/polska-w-ue/news-premierskieruje-do-tk-wniosek-o-rozstrzygniecie-sporu-z-tsu,nId,4428748.

"Rule of Law: European Commission launches infringement procedure to protect judges in Poland from political control." 2019. Text. European Commission -

European Commission. April 3, 2019.

https://ec.europa.eu/commission/presscorner/detail/pt/IP_19_1957. 
"Rule of Law Framework." n.d. Text. European Commission - European Commission. Accessed April 14, 2020. https://ec.europa.eu/info/policies/justiceand-fundamental-rights/upholding-rule-law/rule-law/rule-law-framework_en.

Sadurski, Wojciech. 2019. Poland's Constitutional Breakdown. Oxford, England: Oxford University Press.

Sanchez Urribarri, Raul A. 2011. "Courts between Democracy and Hybrid Authoritarianism: Evidence from the Venezuelan Supreme Court.” Law \& Social Inquiry 36 (4): 854-884. https://doi.org/10.1111/j.1747-4469.2011.01253.x.

"Sędzia Paweł Juszczyszyn zawieszony." 2019. gazetapl. November 29, 2019. https://wiadomosci.gazeta.pl/wiadomosci/7,114884,25461959,sedzia-paweljuszczyszyn-zawieszony-domagal-sie-list-poparcia.html.

Solomon, Peter. 2007. "Review Article: Courts and Judges in Authoritarian Regimes." World Politics 6o (1): 122-145.

"Stanowisko Ministerstwa Sprawiedliwości w sprawie zmian dotyczących aktywności sędziów.” 2019. Ministerstwo Sprawiedliwości. December 13, 2019.

https://www.gov.pl/web/sprawiedliwosc/stanowisko-ministerstwa-sprawiedliwosciw-sprawie-zmian-dotyczacych-aktywnosci-sedziow.

The Constitution of the Republic of Poland. 1997.

“To Oni Zajmą Się Przewinieniami Kolegów Po Fachu.” 2018. September 21, 2018. https://tvn24.pl/polska/10-czlonkow-izby-dyscyplinarnej-kim-sa-lista-ra8699542392295 .

Ustawa z dnia 20 grudnia 2019 r. o zmianie ustawy - Prawo o ustroju sq̨dów powszechnych, ustawy o Sądzie Najwyższym oraz niektórych innych ustaw. 2019. http://prawo.sejm.gov.pl/isap.nsf/DocDetails.xsp?id=WDU20200000190.

"Wyniki wyborów 2019 do Sejmu RP." 2019. 2019. https://sejmsenat2019.pkw.gov.pl/sejmsenat2019/pl/wyniki/sejm/pl.

"Wyrok TSUE Ws. Sądu Najwyższego. Zbigniew Ziobro: Trybunał Orzekł to, Czego Się Spodziewałem.” 2019. PolskieRadio24.Pl. November 19, 2019.

https://polskieradio24.pl/art1222_2406118. 